\title{
Hospedeiros alternativos de Pantoea ananatis
}

\author{
Alessandra Alves Martins ${ }^{*}{ }^{\oplus}$, Lara Caroline Borges Moreira Mota $^{2} \oplus$, Nilvanira Donizete Tebaldi ${ }^{3}$
}

${ }^{1}$ Graduanda em Agronomia, Instituto de Ciências Agrárias, da Universidade Federal de Uberlândia, Av. Amazonas s/n, Bloco 2E-119, Campus Umuarama, CEP 38.400-902, Uberlândia-MG, Brasil. ${ }^{2}$ Técnica de Laboratório, Instituto de Ciências Agrárias, da Universidade Federal de Uberlândia, Av. Amazonas s/n, Bloco 2E-119, Campus Umuarama, CEP 38.400-902, Uberlândi-MG, Brasil. ${ }^{3}$ Professora Associada, do Instituto de Ciências Agrárias, da Universidade Federal de Uberlândia, Av. Amazonas s/n, Bloco 2E-119, Campus Umuarama, CEP 38.400-902, Uberlândia, MG, Brasil. *Bolsista de Iniciação Científica, CNPq.

Autor para correspondência: Nilvanira Donizete Tebaldi (nilvanira.tebaldi@ufu.br)

Data da chegada: 17/04/2018. Aceito para publicação em: 15/03/2020

$10.1590 / 0100-5405 / 195102$
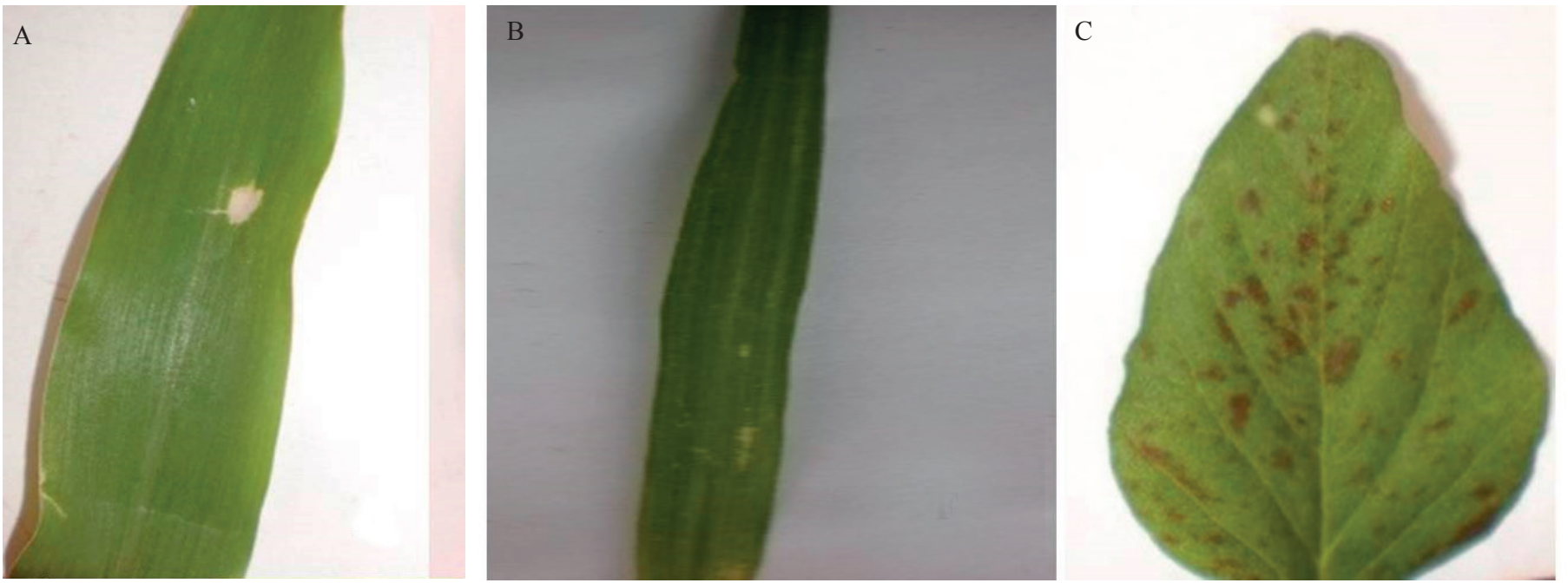

Figura 1. Sintomas da mancha branca, causada pela bactéria Pantoea ananatis, em folhas de milho (A), capim carrapicho (B) e caruru (C).

A mancha branca do milho causada pela bactéria Pantoea ananatis corrig. (Serrano 1928) Mergaert et al. 1993 (4) pode levar a perdas de até $60 \%$ na produção de grãos da cultura (1). As plantas infestantes presentes na cultura podem ser hospedeiras alternativas da bactéria, atuando como fonte de inóculo do patógeno. O objetivo do trabalho foi avaliar hospedeiros alternativos da bactéria $P$. ananatis entre plantas invasoras na cultura do milho. $\mathrm{O}$ experimento foi conduzido em casa de vegetação e no Laboratório de Bacteriologia Vegetal, do Instituto de Ciências Agrárias da Universidade Federal de Uberlândia. Em vasos de capacidade de $500 \mathrm{~mL}$, contendo substrato solo, areia e húmus, foi feita a semeadura do milho e o plantio de mudas das plantas infestantes: capim braquiária (Urochloa decumbens (Stapf) R.D. Webster), capim colchão (Digitaria horizontalis Willd.), capim colonião (Panicum maximum Jacq.), capim carrapicho (Cenchrus echinatus L.), caruru (Amaranthus deflexus L.) e guanxuma (Malvastrum coromandelianum (L.) Garcke), as quais foram inoculadas por aspersão com uma suspensão bacteriana $\left(10^{8}\right.$ UFC mL-1, $\left.\mathrm{OD}_{550}=0,1\right)$ do isolado UFU B13 de $P$. ananatis provenientes de plantas de milho, quando as plantas apresentavam de duas a três folhas. A severidade da doença foi avaliada usando uma escala de notas, variando de zero a quatro, onde: nota $0=$ planta sem sintomas; $1=$ até $25 \%$ da área da folha apresentando manchas; $2=25 \%$ a $50 \%$ da área da folha com manchas; $3=$ mais de $50 \%$ da área da folha com manchas; $4=$ planta apresentando desfolha e seca. Das plantas infestantes com sintomas de mancha branca foi feito o reisolamento da bactéria em meio de cultura 523 (3) e os isolados caracterizados cultural e bioquimicamente pelos testes de: Gram em KOH 3\%, oxidação ou fermentação da glicose, crescimento em meio YDC (5). As plantas de milho, caruru e capim carrapicho apresentaram sintomas de mancha branca (Figura 1), aos 3, 6 e 9 dias após a inoculação, respectivamente. Os isolados apresentaram colônias amarelas brilhante com aspecto liso, bordos regulares em meio 523, Gram negativa, oxidação/fermentação: anaeróbica estrita e colônias amarelas no meio YDC. Nas demais plantas infestantes não foram observadas os sintomas da doença. $P$. ananatis também foi isolada de pequenas lesões foliares de capim colchão (2), em que os testes de patogenicidade reproduziram sintomas semelhantes aos causados em plantas de milho e os mesmos isolados foram patogênicos à diferentes híbridos de milho (6). Sendo, portanto as plantas infestantes capim carrapicho e caruru hospedeiras alternativas de $P$. ananatis. Conhecendo os hospedeiros alternativos de $P$. ananatis pode-se ter uma maior cautela na eliminação de plantas infestantes no campo, impedindo que estas sejam uma fonte de inóculo primário da bactéria, para a próxima estação de cultivo, principalmente no cultivo do milho de segunda safra. Esta medida poderá auxiliar o manejo da mancha branca do milho no campo.

\section{REFERÊNCIAS}

1. Casela, C.R.; Ferreira, A.S.; Pinto, N.F.J.A. Doenças na cultura do milho. Sete Lagoas: Embrapa, 2006. 14p. (Circular Técnica, 83).

2. Gonçalves, R.M.; Pedro, E.S.; Meirelles, W.F.; Paccola-Meirelles, L.D. Capim-colchão: hospedeiro alternativo de Pantoea ananatis, agente causal da mancha branca do milho. In: Congresso Nacional de Milho e Sorgo, 28., 
2010, Goiânia. Associação Brasileira de Milho e Sorgo, 2010. 1 CD-ROM.

3. Kado, C.I.; Heskett, M.G. Selective media for isolation of Agrobacterium, Corynebacterium, Erwinia, Pseudomonas and Xanthomonas. Phytopathology, St Paul, v.60, p.969-976, 1970.

4. Paccola-Meirelles, L.D.; Ferreira, A.S.; Meirelles, W.F.; Marriel, I.E.; Casela, C.R. Detection of a bacterium associated with a leaf spot disease of maize in Brazil. Journal of Phytopatology, Berlin, v.149, n.5, p.275-279, 2001.
5. Schaad, N.W.; Jones, J.B.; Chun, W. Laboratory guide for identification of plant pathogenic bacteria. In: Coplin, D.L.; Kado; C.I. Gram-negative bacteria, Pantoea. 3rd ed. St. Paul: APS, 2001. p.73-83.

6. Silva, D.D.; Costa, R.V.; Cota, L.V.; Parreira, D.F.; Lana, U.G.P.; Ferreira, P.; Nolasco, A.A.R.; Souza, I.R.P.; Marriel, I.E. Inoculação cruzada de isolados de Pantoea ananatis de milho e capim-colchão. Tropical Plant Pathology, Brasília, DF, v.35, p.127, 2010. 